KEMÉNY Ildikó - SIMON Judit

\title{
TERMÉKEK ÉS SZOLGÁLTATÁSOK VÁSÁRLÁSA ON-LINE - VAJON MÁSOK AZ ELVÁRÁSOK?
}

Az on-line vásárlás a kiskereskedelem napjaink egyik legdinamikusabban fejlódó területe. Az elmúlt években számos tanulmány foglalkozott az elektronikus kiskereskedelem marketingszempontú vizsgálatával, azonban ez idáig kevesen foglalkoztak a termékeket és szolgáltatásokat vásárlók elkülönült vizsgálatával. A szerzốk célja, hogy egy kvantitatív kutatás alapján a minốségészleléssel és elégedettséggel összefüggésben megvizsgálják az újravásárlási, illetve a továbbajánlási szándék alakulását konkrét e-kiskereskedelmi vásárlások - termékek vagy szolgáltatások vásárlása - esetében. Eredményeik alapján megállapítható, hogy a szolgáltatást on-line vásárlók esetében az elégedettség hatása a továbbajánlási és újravásárlási szándékra alacsonyabb szintet mutat, mint a terméket vásárlók esetében. A minőségészleléshez kapcsolódó dimenziók között is megfigyelhetố egy releváns eltérés: a terméket vásárlók esetében az ügyfélszolgálat relevanciájában a minôségészlelés során, kvázi, azokban az esetekben, amikor a vásárlás után hátra van még a tényleges kiszállítás vagy kézhezvétel. A rendelkezésükre álló minta nagysága miatt elemzésük során a varianciaalapú modellezést (PLS-SEM) használták.

Kulcsszavak: továbbajánlási szándék, elektronikus minôségészlelés, varianciaalapú modellezés

Az elmúlt tíz évben az B2C on-line kereskedelem a hazai piacon is rohamos fejlődést mutatott: 2012-ben már 177 milliárd forintot költöttek el a vásárlók a kosaras rendszerben múködô webshopokban, mely 2011-hez képest 22 milliárdos növekedést jelent. Megközelítőleg 6000 magyar nyelvú webáruház érhetô el jelenleg az interneten, és a 14 éven felüli vásárlók száma 1,65 millió foóre tehető (Enet, 2013).

A töretlen sikert az e-kereskedelem a kínált előnyeinek - például a kényelmesség, nagyszámú választék és információmennyiség, 24/7 elérhetóség - is köszönheti, azonban a tapasztalatok gyarapodásával a fogyasztói elvárások egyre magasabbra törnek, és a sikeres múködés szempontjából az észlelt minőség alakulása kerül a középpontba.

Jelen tanulmány célja, hogy megvizsgálja az észlelt elektronikus szolgáltatásminôség dimenziójának hatását a konkrét vásárlási szituációhoz köthetô elégedettség, a továbbajánlási és újravásárlási szándék esetében. A munkánk során az e-szolgáltatás minőségé t Wolfinbarger és Gilly munkája alapján (2003) négy látens dimenzió mentén mértünk: a design, a megbízhatóság, a biztonság és az ügyfélszolgálat. Mivel Francis és White (2003), valamint Parasuraman és társainak (2005) tanulmányai alapján az e-kereskedelmet érdemes a vásárolt termék jellege alapján (termék vagy szolgáltatás) differenciáltan vizsgálni, tanulmányunk központi kérdése, hogy az előbb említett kapcsolatok vajon különböznek-e a szolgáltatást, valamint a terméket on-line vásárlók esetében.

A tanulmány első részében a témához kapcsolódó koncepciókat és fogalmakat - úgymint elektronikus szolgáltatásminôség, elégedettség, továbbajánlás, újravásárlás - elemezzük, majd saját kutatásunk eredményeit mutatjuk be.

\section{Az elektronikus szolgáltatás minôsége és következményei az e-kereskedelemben}

Az internet terjedésének korai szakaszában a cégek azt hitték, hogy az alacsony ár, illetve a webes jelenlét elegendố a sikerhez (Minocha et al., 2006; Kim et al., 2006). Az on-line környezetbeli fogyasztói és vál- 
lalati tapasztalatok gyarapodásával, a verseny élesedésével és az internetes vásárlás rutinná válásával (Yoo - Donthu, 2001) azonban rá kellett döbbenniük arra, hogy ez nem elég. Amennyiben a kívánt információk nem érhetók el a honlapon, a vállalat nem válaszolja meg az e-maileket idóben, vagy a terméket nem küldik a megígért idôpontban, a fogyasztók sokkal alacsonyabbra értékelik az adott cég által nyújtott minôséget (Zeithaml et al., 2002), és a jövóben az on-line vásárlásuk lebonyolításához a versenytársakat fogják választani. Ennek felismerése új stratégiai gondolkodást hívott életre, és hamarosan a minóség sarkalatos pontjává vált az internetnek mint csatornának. Azonban a szükséges szakirodalom a 2000-es évek közepéig hiányzott (Parasuraman et al., 2005).

On-line környezetben egy termék vagy szolgáltatás vásárlása más élményt nyújt, mint a hagyományos, off-line környezetben. Ilyenkor a vásárlók az üzlettel a virtuális térben „kommunikálnak”, az interperszonális interakció helyét egy ember - gép interakció veszi át, melynek középpontjában a technológia áll (Bressolles et al., 2007), és megnó az önkiszolgáló metódusok jelentôsége. Az internet csatornaként számos újfajta előnyt nyújt, mint például a kétirányú kommunikáció, személyre szabás, közösség szerepe, növekvő információ- és termékválaszték, melyek szintén egy újfajta, az off-line-tól eltéró minôségmegközelítést követelnek meg (Wolfinbarger - Gilly, 2003). Az internetes vásárlás előnyei, úgymint a 24/7 elérhetôség (Seiders et al., 2000), az összehasonlítási lehetőségek (Wolfinbarger - Gilly, 2001), az önkiszolgálás a kontroll érzetét nyújtják, illetve egyfajta szabadságot biztosítanak az eladóktól, a családtól, a szociális érintkezésektől. Azonban hátrányai is léteznek a folyamatnak, például a kiválasztott terméket nem foghatjuk meg, nem beszélhetünk az eladókkal. Ebben a személytelen, automatizált környezetben kevesebb direkt érzéki stimulus éri a vásárlókat, a csalási és visszaélési lehetôségek miatt nagyobb a bizonytalanság érzete, így kiemeltebb figyelmet kap a biztonság kérdése (Bressolles et al., 2007). E sajátosságok alapján megállapítható, hogy az elektronikus kereskedelemhez tartozó szolgáltatásminőség a tradicionálistól eltérô megfogalmazást igényel.

Az e-kereskedelemhez kapcsolódó szolgáltatásminôséget a szakirodalomban is használatos elektronikus szolgáltatásminőség kifejezéssel illetjük, mely magába foglalja, hogy egy webshop milyen szinten képes a hatékony és eredményes nézelődést, vásárlást, illetve kiszállítást támogatni (Parasuraman et al., 2005).

A hagyományos résmodellben (GAP) felrajzolt szakadékok az elektronikus szolgáltatásminőség esetében is tetten érhetốk (Zeithaml et al., 2002), és ezek együttes hatása befolyásolja a szolgáltatásminőség értékelését $(\mathrm{G} 5=\mathrm{f}(\mathrm{G} 1 ; \mathrm{G} 2 ; \mathrm{G} 3 ; \mathrm{G} 4))$, mely hatással bír az elégedettségre, ezáltal pedig a továbbajánlásra és újravásárlásra (1. ábra).

1. ábra

A résmodell alakulása elektronikus kereskedelem esetében

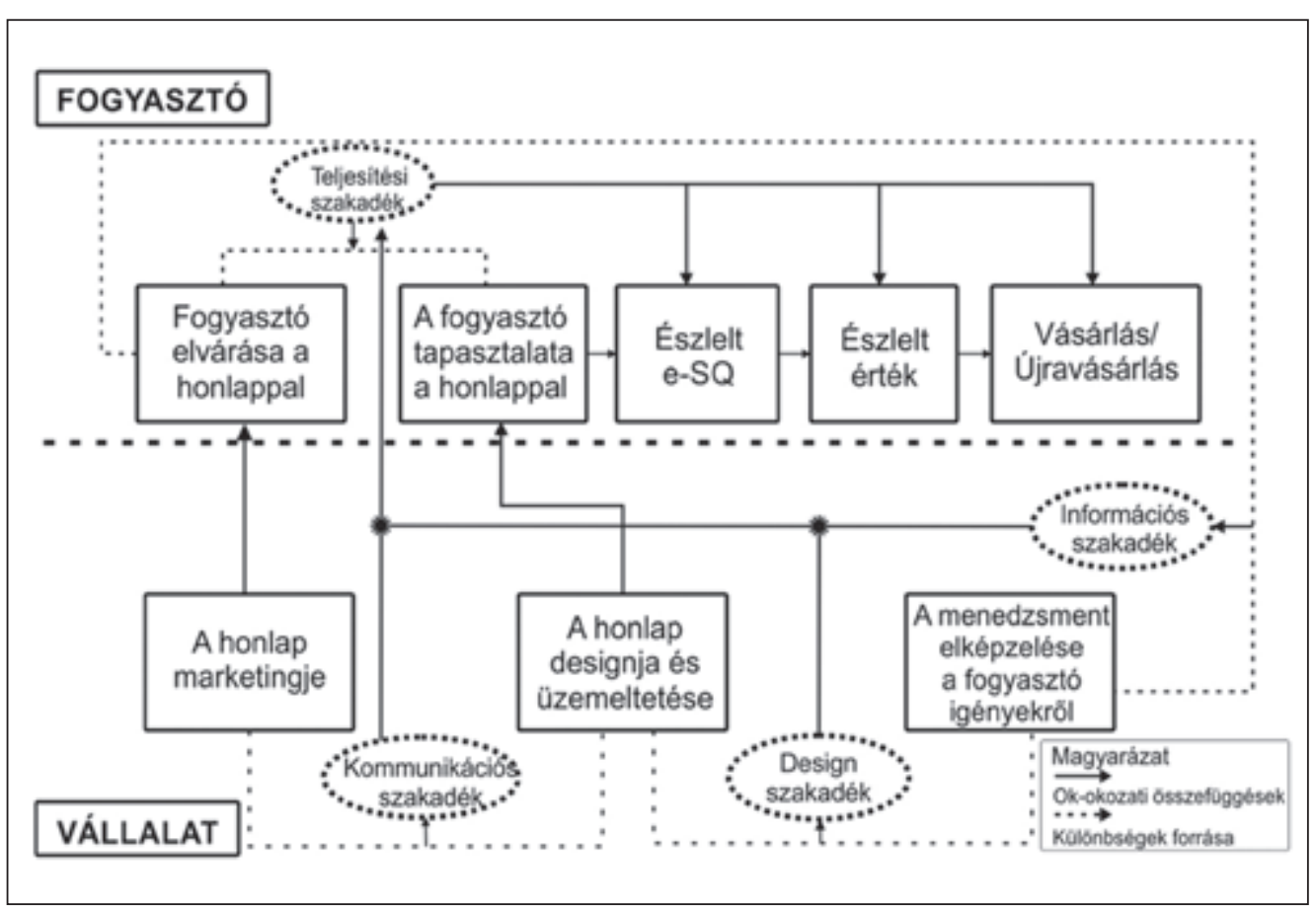

Forrás: Zeithaml et al. (2002)

Parasuramanék szerint (2002) az elektronikus szolgáltatás minősége esetében egy görbe pályájú kapcsolat figyelhetô meg, és létezik egy telítődési pont (invertált U görbe). Az általuk felhozott példa szerint a vásárlók szeretnek visszajelzést kapni arról, hogy a rendelésüket elfogadták-e, valamint az utánkövetô e-mailek is fonto-

\section{VEZETÉSTUDOMÁNY}


sak, de van egy pont, amikor már elég a levelekból, és a további információáradat a minőség rontásához, ezen keresztül pedig a vásárlói elégedettség csökkenéséhez vezet.

\section{Az elégedettség és annak következményei}

Az elégedettség számos pozitív, jövedelmezô hatást hordoz egy vállalat számára. Az elégedett vevô újravásárlásai során visszatér a vállalathoz, illetve jó hírét viszi a cégnek (Szymanski - Henard, 2001; Chang et al., 2009). A pozitív szájreklámmal támogatja az új vásárlók megszerzését, ezzel csökkentve a vevőszerzés költségét. Az elégedett vásárlók jellemzóen megbocsájtóbbak a szolgáltatók hibáival kapcsolatban, és érzéketlenebbek a konkurensek ajánlataira, tehát a vállalat versenyelőnyét támogatják (Kenesei - Kolos, 2007), hosszú távon pedig lojálissá tehetôk (Cronin Taylor, 1992). Igaz, hogy az elégedettség és a húség között bonyolult kapcsolati viszony áll fenn, azonban megfelelő stratégia mellett a vevők többsége lojálissá tehető (Hofmeister-Tóth et al., 2003).

A szájreklám a vásárlási döntési szituációban egy jelentôs, külső információforrást jelent, amit olyan egyén vagy vállalkozás indíthat, akinek tapasztalata van az adott termékkel, szolgáltatással kapcsolatban, és ennek köszönhetően megfelelő információt juttat el a befogadó számára (Eszes, 2011). A szájreklám a szolgáltatások esetében különösen jelentős hatással bír (Kenesei - Kolos, 2007). „A szájreklám (word of mouth) informális pozitív vagy negatív tartalmú kommunikációt jelent az ügyfelek között, egy vállalatról, annak termékéról vagy szolgáltatásáról" (Tax et al., 1993: p. 74 in: Neumann-Bódi, 2012). Napjainkban megkülönböztetünk hagyományos és off-line szájreklámot is, azonban jelen kutatás kereteiben mi csak a hagyományos szájreklámmal foglalkozunk.

Az elégedettség hatását a vásárlás utáni magatartásban (pl. szájreklám és újravásárlás) tanulmányok támogatják (Kim, 2005). A fogyasztó elégedettsége a korábbi vásárlási tapasztalatait figyelembe véve alakult ki egy adott elektronikus kereskedelmi céggel, amely befolyásolja az újravásárlási szándékot (Hsu et al., 2012). Wolfinbarger és Gilly (2003) eredményei alapján megállapítható, hogy az általuk megalkotott eTAILQ elektronikus szolgáltatásminőség-skála esetében a fogyasztói elégedettségben a megbízhatóság dimenziója bizonyult a legfontosabbnak, és ha a minôségdimenziók közvetlen hatását vizsgáljuk az újravásárlási szándékra, akkor ez a második legfontosabb tényező. Loiacono, Watson, Goodhue (2007) eredményei is alátámasztják az elégedettség hatását az újralátogatásra, illetve az újravásárlásra. A tényt, hogy az elégedettség befolyásolja a vásárlási szándékot és a szájreklámot Dolen, Dabholkar és Buyter (2007 in: Moon - Moon, 2011) eredményei is igazolják. Muthaly és Akamavi (2010) kutatása alapján is elfogadható az a feltevés, hogy az elégedettség közvetlenül befolyásolja az online újravásárlási szándékot. Kim (2012) szerint az elégedettség vizsgálata on-line környezetben az újravásárlással kapcsolatban azért is fontos, mert sokszor a fizetés a szállítás előtt történik, ezért bizalmat kell az eladónak biztosítani. Amennyiben a fogyasztó elégedetett, közös megértés alakul ki, és sokkal valószínúbb, hogy a kapcsolatuk folytatódik. Amennyiben az elégedettség a teljesítménnyel kapcsolatban nő, akkor a tranzakciók megismétlésének szándéka - újravásárlási szándéka - is nő (Kim, 2012).

\section{Az e-kereskedelem lehetséges csoportosítása}

Az e-kereskedelem csoportosítása több módon történhet, melyek közül egy lehetséges megoldás az értékesített jószág (termék és/vagy szolgáltatás) és a teljesítés módja (off-line - elektronikus) szerinti felosztás. Adam szerint (2002) a vállalatok internetes használati szokásai a kereskedelem területén a tiszta (pure) offline és tiszta (pure) on-line kontinuumban mozognak, melynek középpontját a ,clicks-and-bircks” boltok adják. Mások az e-kereskedelem sajátosságait a szállítás módjában látják: szerintük célszerú eltérô fókusszal vizsgálni a postán vagy futárral szállítókat, illetve azokat, akik elektronikusan szállítanak (Francis - White, 2002; Wolfinbarger - Gilly, 2003). Ez a fajta on-line off-line csoportosítás egy jó marketingalapú megoldás, azonban továbbra sem fedi le a teljes e-kereskedelmet: egyik csoportba sem sorolhatók be egyértelmúen azok a termékek/szolgáltatások, melyeket kifizetnek és egyból on-line el is fogyasztanak a vásárlók.

Ezt a gondolatmenetet felhasználva Francis és White (2003) megkülönbözteti az on-line/elektronikus, illetve off-line teljesítés kategóriáját (2. ábra). On-line teljesítés esetében a vásárlónak a tranzakció után az elektronikus környezetben kell „maradnia”, hogy letöltse vagy elfogyassza a terméket, míg off-line esetben a megrendelés után elhagyhatja a virtuális világot. Az általuk megalkotott elektronikus kereskedelmi csoportosítás egyik dimenzióját ez adja. A megkülönböztetés másik tényezője, hogy kézzel fogható termékeket vagy nem megfogható szolgáltatásokat értékesít-e az on-line áruház. Ezek alapján egy $2 \times 2$-es mátrix alakul ki négy kategóriával (Francis - White, 2003): (1) off-line termékek, (2) off-line szolgáltatások, (3) elektronikus termékek és (4) elektronikus szolgáltatások. 
Az e-kereskedelem kategóriái a teljesítés módja és a termék jellege szerint

\begin{tabular}{|c|c|c|c|}
\hline & \multicolumn{2}{|c|}{ TELJESITÉSS MÓDJA } \\
\hline & & Off-line & Elektronikus \\
\hline \multirow{4}{*}{ 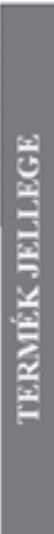 } & & Off-line-termékek & E-termékek \\
\hline & 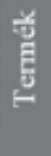 & $\begin{array}{l}\text { A vásárló on-line rendel, azonban off- } \\
\text { line kapja meg a terméket } \\
\text { pl. könyv, mobiltelefon, bútor }\end{array}$ & $\begin{array}{l}\text { A vásárló fizetés után egybōl letőlti a } \\
\text { terméket, és elökésziti a fogyasztásra } \\
\text { pl. szoftverek, MP3, e-újságok }\end{array}$ \\
\hline & & Off-line-szolgáltatások & E-szolgáltatások \\
\hline & 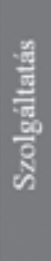 & $\begin{array}{l}\text { A rendelés on-line történik, de az egyén } \\
\text { off-line kell, hogy eljusson a } \\
\text { szolgáltatóhoz } \\
\text { pl. utazás, szállás, belépôjjegyek, } \\
\text { masszázs }\end{array}$ & $\begin{array}{l}\text { Egy felhasználói fiókot hoz létre az egyén, } \\
\text { mely szükséges ahhoz, hogy } \\
\text { elfogyaszthassa a fó szolgáltatást } \\
\text { pl. e-banking, chat szobák, } \\
\text { részuénykereskedés }\end{array}$ \\
\hline
\end{tabular}

Forrás: Francis - White (2003)

Az off-line termék esetében a vásárló on-line rendel, azonban off-line kapja meg a terméket (pl. könyv, mobiltelefon, bútor). Az off-line szolgáltatásoknál is a rendelés on-line történik, de az egyén off-line kell, hogy eljusson a szolgáltatóhoz (pl. utazás, szállás, belépójegyek, masszázs) vagy a szolgáltató az egyénhez. Ezen esetek többségében a késleltetett fizetés (pl. átvétel), valamint a késóbbi termékcsere-folyamat a jellemzó (Francis - White, 2003). Ezzel szemben az elektronikus termékek esetében a vásárló fizetés után egyból letölti a terméket, és elókészíti a fogyasztásra (pl. szoftverek, MP3, elektronikus újságok), míg az elektronikus szolgáltatás vásárlásakor egy felhasználói fiókot hoz létre az egyén, mely szükséges ahhoz, hogy elfogyaszthassa a fő szolgáltatást (pl. e-banking, chat szobák, részvénykereskedés) (Francis - White, 2002, 2003).

Az elektronikus kereskedelem esetében a teljes vásárlási folyamat annak függvényében, hogy a Francis és White (2003) által megalkotott négy terület közül melyikról beszélünk, eltérôen alakulhat. Ezeknek a különbségeknek a tisztázása azért fontos, hogy az elektronikus szolgáltatásminőség-dimenziót a jövőben a lehető legpontosabban tudjuk meghatározni.

Függetlenül attól, hogy melyik területról beszélünk, a döntés elôtti információkeresés kiemelt szereppel bír, vagyis az, hogy a kívánt információk a webshop honlapján hogyan érhetók el. A szükséges információk összegyưjtése, értékelése és a döntés megszületése után veszi kezdetét a vásárlási tranzakció lebonyolítása, mely magába foglalja a kiválasztott termék vagy szolgáltatás megjelölését, a „kosárban történő elhelyezését", a szükséges adatok bevitelét, majd a pénzügyi
2. ábra teljesítést, mely történhet kártyával, átutalással vagy off-line teljesítés esetében az átvételkor, készpénzben. Látszólag az információgyưjités és tranzakció lebonyolítása hasonlóan alakul a négy kategóriában. A késóbbiekben a szakirodalom alapján is megvizsgálom, hogy az ide tartozó minőségdimenziók esetében megfigyelhető-e eltérés.

A megvásárolt termék, illetve szolgáltatás átvételének módjában már jelentős különbségek adód(hat)nak. Off-line termékek esetében lehetőség van a kiszállításra (posta, futár stb.) vagy egy felvevőponton való átvételre. Off-line szolgáltatásoknál az igénybevételre jogosító utalványt vagy jegyet elektronikus (pl. e-mailben) vagy postai úton tudja az eladó a vásárlóhoz eljuttatni, és ennek az igazolásnak a birtokában lehetséges a vásárolt szolgáltatást igénybe venni (pl. színház, masszázs, utazás). Az elektronikus termékek elfogyasztásakor azonban az egyén a gép előtt marad, és onnan tudja letölteni azt (pl. zene, software), míg az elektronikus szolgáltatások esetében valamilyen regisztrált fiókon keresztül lehetséges a szolgáltatás igénybevétele (pl. on-line átutalás, biztosításkötés, játék).

Bármelyik esetben a tranzakció közben vagy után fellépó problémák, kérdések kezelése is az elektronikus szolgáltatás minôségdimenziójába tartozik, ezért a minôségkoncepciók értékelésekor ezt is figyelembe kell venni. Kutatásunk során a kis mintaelemszám miatt a Francis és White által megalkotott dimenziók közül csak a vásárolt termék jellege alapján csoportosítjuk az e-kereskedelmet, azonban az eddigi tanulmányokhoz képest ez is jelentős újdonságokat tartalmazhat a differenciált vizsgálat (terméket vagy szolgáltatást vásárol) alapján.

\section{A kutatásról}

A szakirodalmi összefoglalás legfontosabb eredményeit és a megjelölt limitációkat figyelembe véve indítottuk el jelen kutatásunkat, melyben egy olyan szolgáltatásminôség-skála került használatra, melyet termékek és szolgáltatások esetében is teszteltek már. A minôségészlelés mellett az elégedettség és annak bizonyos pozitív következményeit, úgymint a szájreklámot, illetve az újrahasználati szándékot, is mértük. 
A kutatás során célunk a 30 év alatti fiatalok elérése volt. A két hétig tartó on-line megkérdezés során 148 válaszadónk lett. A kérdőívben az általános on-line vásárlási szokások megismerése után került sor a legutolsó vásárláskor használt webshop értékelésére.

A szakirodalom alapján az alábbi hipotéziseket állítottuk fel:

H1a: Szolgáltatások vásárlásakor az elektronikus szolgáltatás minósége pozitív hatással van az elégedettségre.

H1a: Termékek vásárlásakor az elektronikus szolgáltatás minôsége pozitív hatással bír az elégedettségre.

Hivatkozott irodalom: Parasuraman et al., 1985; Cronin-Taylor, 1992; Veres, 1999; Wolfinbarger - Gilly, 2003; Gummerus et al., 2004; Chang, 2005; Parasuraman et al., 2005; Bressolles et al., 2007; Yang - Tsai, 2007; Godwin et al., 2010. Függó változó: elégedettség - használt skála: Chang - Wang - Yang, 2009.

Független változó: elektronikus szolgáltatásminôség - használt skála: ETAILQ, Wolfinbarger - Gilly, 2003.

H2a: Szolgáltatások vásárlásakor az elektronikus szolgáltatás minôsége pozitív hatással van az újravásárlási szándékra.

H2b: Termékek vásárlásakor az elektronikus szolgáltatás minôsége pozitív hatással van az újravásárlási szándékra.

Hivatkozott irodalom: Parasuraman - Zeithaml - Berry, 1988, 1991; Taylor - Baker, 1994; Zeithaml - Berry - Parasuraman, 1996; Cronin et al., 2000; Godwin et al., 2010.

Függó változó: újravásárlási szándék - használt skála: Godwin-Bagchi-Kirs, 2010.

Független változó: elektronikus szolgáltatásminóség - használt skála: ETAILQ, Wolfinbarger - Gilly, 2003.

H3a: Szolgáltatások vásárlásakor az elektronikus szolgáltatás minôsége pozitív hatással van a szájreklámra.

H3b: Termékek vásárlásakor az elektronikus szolgáltatás minôsége pozitív hatással van a szájreklámra. Függó változó: szájreklám - skála: Zeithalm et al., 1996.

Független változó: elektronikus szolgáltatásminóség - skála: ETAILQ, Wolfinbarger - Gilly, 2003.

H4a: Szolgáltatások vásárlásakor az elégedettség pozitív hatással van az újravásárlási szándékra.
H4b: Termékek vásárlásakor az elégedettség pozitív hatással van az újravásárlási szándékra.

Hivatkozott irodalom: Cronin - Taylor, 1992; Brady - Robertson, 2001; Godwin et al., 2010;

Függó változó: újravásárlási szándék - skála: Godwin - Bagchi-Kirs, 2010.

Független változó: elégedettség - skála: Chang - Wang - Yang, 2009.

H5a: Szolgáltatások vásárlásakor az elégedettség pozitív hatással van a szájreklámra.

H5b: Termékek vásárlásakor az elégedettség pozitív hatással van a szájreklámra.

Hivatkozott irodalom: Dolen - Dabholkar Buyter, 2007; Ltifi - Gharbi, 2012.

Függó változó: szájreklám - Zeithalm et al., 1996.

Független változó: elégedettség - skála: Chang

- Wang - Yang, 2009.

\section{A minta jellemzói}

A válaszadóink 68\%-a volt nô, többségük a 19-26 éves korosztályba tartozott (91\%) és a fóvárosban él (65\%). A mintába kerültek közel fele (44\%) még a felsőoktatásban tanul. A válaszadók többsége ritkábban mint kéthavonta szokott on-line vásárolni (45\%), azonban jelentôs a havonta interneten vásárlók aránya is (30\%). A legnépszerúbb általában vásárolt termék a könyv, valamint a meleg étel: a válaszadók $17 \%$ illetve 13\%-a jelölte meg ezeket, míg a szolgáltatásoknál a többség mozi-, színház vagy egyéb belépójegyet (16\%), valamint utazást és repülőjegyet (15\%) szokott az interneten vásárolni.

A megkérdezettek 44\%-ának a legutolsó on-line vásárlása kevesebb, mint két hete történt, melynek során a többség könyvet (20\%), meleg ételt (16\%), valamilyen belépójegyet (14\%) vagy repülőjegyet vásárolt (12\%). Összességében a válaszadók 62,5\%-a terméket, míg 37,5\%-uk valamilyen szolgáltatást vett utolsó vásárlása során. Legtöbben kevesebb, mint 5.000 Ft-ért vásároltak (58\%), azonban jelentős a 20.0000 Ft-ért vásárlók aránya is (12\%). A megkérdezettek 43\%-a az átvételkor fizetett a megrendelésért, míg 22\%-uk banki átutalással, 34\%-uk pedig bank-, illetve hitelkártyával.

A legutolsó vásárlásukkor terméket vagy szolgáltatást vevốk között számos jelentős magatartási szokás figyelhető meg. Akik szolgáltatást vettek legutoljára, jellemzően sứrúbben vásárolnak on-line ${ }^{1}$, többségük előre fizetett banki átutalással $(27 \%)$ vagy valamilyen kártyával $(55 \%)^{2}$, valamint jellemzôen magasabb öszszegben történt a legutolsó vásárlásuk: $63 \%$-uk vásárolt $5.000 \mathrm{Ft}$ felett, míg a terméket vevók körében ez mindössze $31 \%$-ot mutat (1. táblázat). 


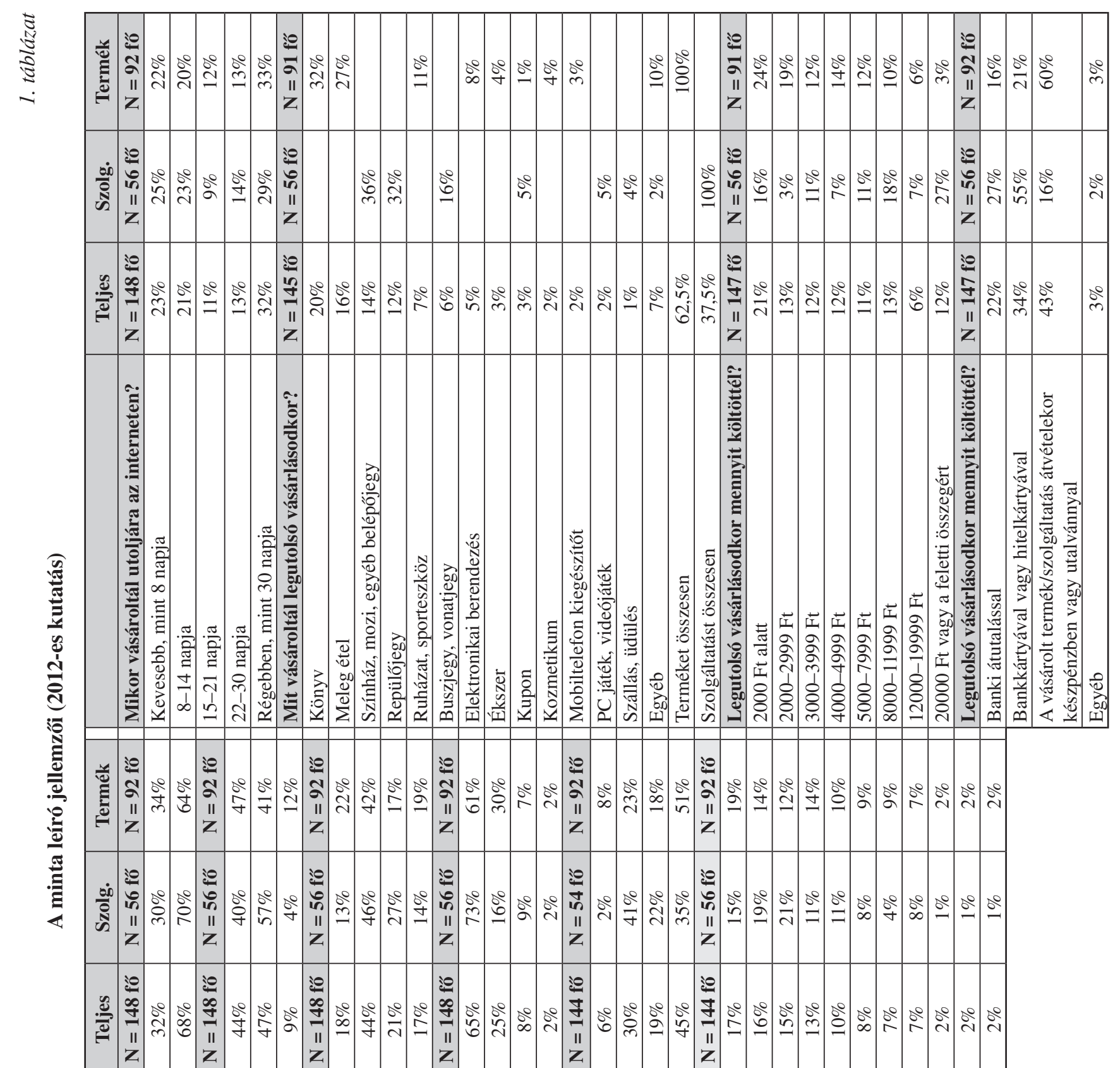




\section{Eredmények}

Kutatásunk során az elektronikus szolgáltatás minôségének hatását kívántuk mérni az elégedettségre, valamint ennek kapcsolatát az újravásárlási szándékkal, illetve a szájreklámmal. A kutatás során alkalmazott skálák megfelelő megbízhatósággal rendelkeznek: a Cronbach-alfa értékek a Nunnaly és Bernstein (1994) által meghatározott 0,7 szint felettiek $(0,795$ és 0,931 közötti érték). A mérési tételek korrelációs együtthatói is elfogadhatóak (Churchill, 1979): a teljes mintán a korreláció 0,398 és 0,88 között mozog, csak a szolgáltatást vásárló részminta esetében 0,28 és 0,89 között, míg a termékeknél 0,42 és 0,87 között (2. táblázat).
Mind a szolgáltatást, mind pedig a terméket vásárlók körében az e-szolgáltatás minôségdimenziói közül 1-tól 7-ig skálán a legjobb átlagos értékelés a megbízhatósághoz tartozik (átlag $\mathrm{m}_{\mathrm{mzz}}=6,6$, átlag ${ }_{\mathrm{mT}}=6,3$ ). A szolgáltatást vásárlók körében leggyengébben a vevốszolgálat dimenziói szerepelt (átlag ${ }_{\mathrm{vsz} z \mathrm{Sz}}=4,8$ ), míg a termékeknél a maradék három dimenzió értékelése hasonló értéket mutat (átlag ${ }_{\mathrm{vsZ}}=5,5$, átlag $\mathrm{bT}_{\mathrm{bT}}=5,6$, $\left.a_{\text {átlag }}{ }_{\mathrm{dT}}=5,8\right)$. Az elégedettség, az újravásárlási szándék, valamint a továbbajánlás változók átlagos értékelése mindkét csoportban hasonlóan alakul (2. táblázat).

Hipotéziseink tesztelésére SmartPLS programot használtunk. Ennek oka, hogy a PLS útelemzés akkor

2. táblázat

Az alkalmazott skálák megbízhatósága

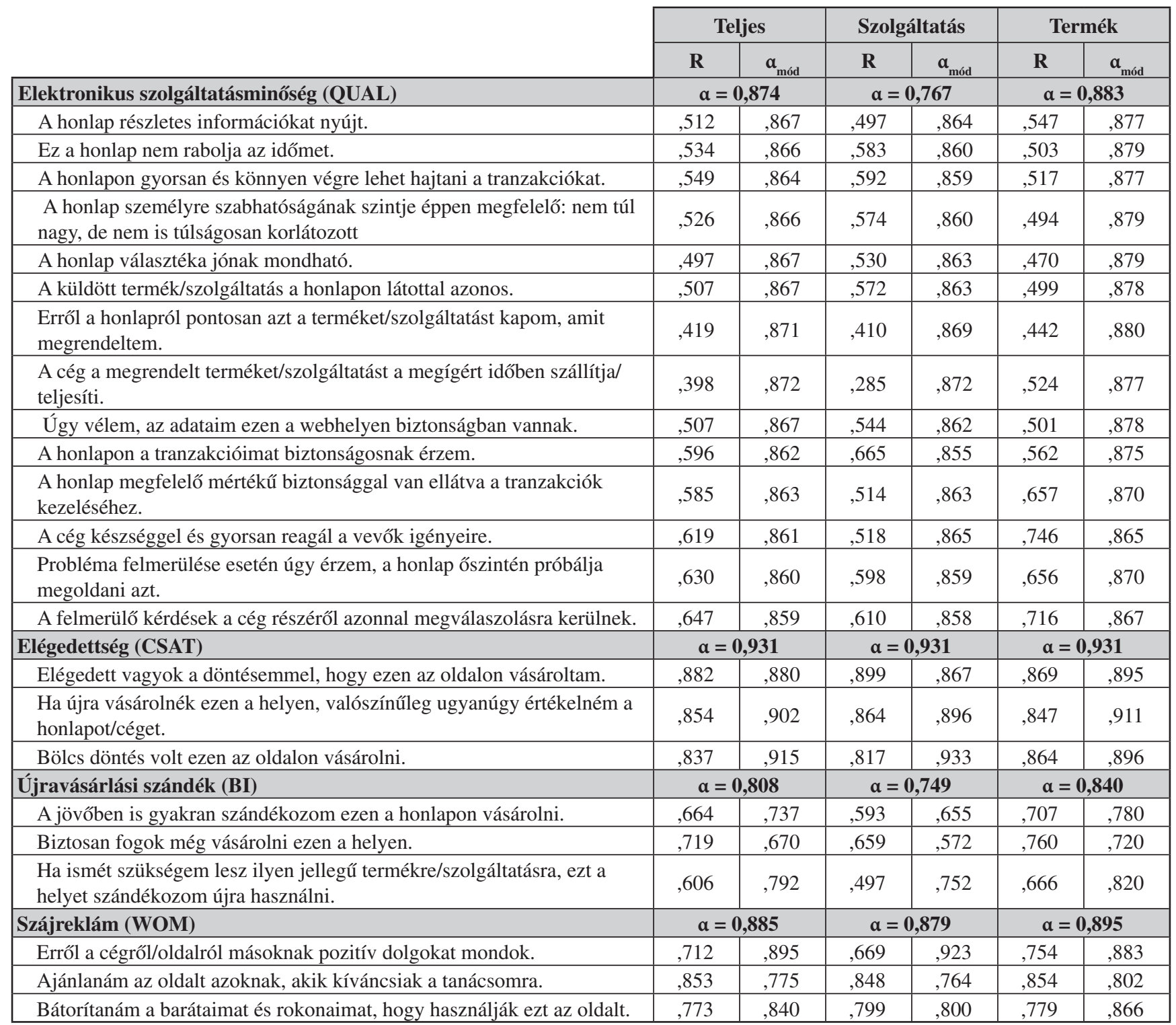

Forrás: eredmények alapján saját szerkesztés

$R$-teljes korreláció; $\alpha_{\text {mód }}$-Cronbach-alfa változása, ha a mérési tételt töröljük 
A használt skálák érvényességi mutatói

\begin{tabular}{|c|c|c|c|c|c|c|}
\hline & Szolgáltatás & Termék & Szolgáltatás & Termék & Szolgáltatás & Termék \\
\hline & \multicolumn{2}{|c|}{ Átlagos magyarázott variancia } & \multicolumn{2}{|c|}{ Dillon-Goldstein's Rho } & \multicolumn{2}{|c|}{ Cronbach-alfa } \\
\hline Vevôszolgálat & 0,7813 & 0,7494 & 0,9146 & 0,8997 & 0,8599 & 0,8325 \\
\hline Design & 0,528 & 0,4856 & 0,8475 & 0,8243 & 0,7736 & 0,7322 \\
\hline Megbízhatóság & 0,6252 & 0,6125 & 0,8256 & 0,8252 & 0,683 & 0,6823 \\
\hline Biztonság & 0,8244 & 0,7231 & 0,9336 & 0,8866 & 0,8926 & 0,8087 \\
\hline $\begin{array}{l}\text { Észlelt minốség } \\
\text { (másodlagos fogalom) }\end{array}$ & 0,5753 & 0,6175 & 0,7886 & 0,7414 & 0,8753 & 0,875 \\
\hline Elégedettség & 0,8639 & 0,8733 & 0,9501 & 0,9539 & 0,9223 & 0,9275 \\
\hline Újravásárlási szándék & 0,6712 & 0,7502 & 0,8596 & 0,9 & 0,7634 & 0,8377 \\
\hline Szájreklám & 0,8158 & 0,8209 & 0,9299 & 0,9321 & 0,8859 & 0,8907 \\
\hline Elvárt érték & \multicolumn{2}{|c|}{$\begin{array}{c}\text { AVE }>0,5 \\
\text { (Fornell }- \text { Larcker 1981) }\end{array}$} & \multicolumn{2}{|c|}{$\begin{array}{c}\text { D-G-R >0,7 } \\
\text { (Vandenbosch 1996) }\end{array}$} & \multicolumn{2}{|c|}{$\begin{array}{c}\alpha>0,7 \\
\text { (Nunnaly }- \text { Bernstein 1994) }\end{array}$} \\
\hline
\end{tabular}

Forrás: eredmények alapján saját szerkesztés

is használható, ha az eloszlás ferde (Bagozzi - Yi, 1994 in: Henseler, 2010), mivel nincsen az eloszlásra feltétel (Fornell - Bookstein, 1982 in: Henseler, 2010), valamint kiküszöböli a kis mintából adódó hibákat is (Henseler et al., 2009). A varianciaalapú modellalkotás az elmúlt időszakban egyre népszerúbb a marketing területén is: 1987 és 2007 között az öt legfontosabb marketingszaklapban húsz ilyen jellegú kutatás jelent meg (Eggert, 2007).

A modellünket külön teszteltük a szolgáltatások, valamint a termékek esetében is. Az eredmények értelmezése előtt azonban meg kell nézni a különböző érvényességi mutatókat, azaz a belsô megbízhatóságét (internal consistency reliability), az indikátor-megbízhatóságét (indicator reliability), a hasonlósági érvényességét (convergence validity), valamint a különbözőségi érvényességét (discriminant validity).

A belsô megbízhatóságot a Cronbach-alfa, illetve Dillon-Goldstein's Rho-féle mutatóval mérhetjük. A Cronbach-alfa értékek a korábban bemutatottaknak megfelelően 0,7-nél magasabb értéket vesznek fel, kivétel a meghízhatóság dimenziója és Dillon-Goldstein ‘s Rho-féle összetételmegbízhatóság-mutató is minden egyes esetben 0,82 feletti értéket mutat. Ezek alapján megfelelő a látens változók belsô megbízhatósága.

A látens változókhoz tartozó hasonlósági érvényesség az átlagos magyarázott varianciaértékkel mérhető, amely megmutatja, hogy ,a skála és ugyanannak a fogalomnak más mérési tételei között mennyiben áll fenn pozitív korreláció” (Malhotra - Simon, 2008: 320. old.). Fornell és Larcker (1981) véleménye alapján 0,5 felett fogadható el az érték. Ez a termékek esetében a design dimenzió kivételével minden egyes változó esetében fennáll ${ }^{3}$ (3. táblázat).
A különbözôségi érvényesség azt mutatja, hogy a skála nem korrelál-e más fogalmak kéréseivel. Ennek ellenőrzésére a Fornell-Larcker-kritériumot használjuk, mely szerint egy látenshez tartozó AVE magasabb kell, hogy legyen, mint a bármely más látenssel alkotott korrelációs négyzetösszeg. Egyetlen egy esetben nem felelünk meg ennek a kritériumnak, az észlelt minőség és design dimenziók esetében. Ennek az ellenállásnak a csökkentése érdekében a legalacsonyabb faktorsúllyal rendelkezô mérési tételt a design esetében törölni kellene.

Az eredmények azt mutatják, hogy egyes változók esetében az érvényességi mutatók nem megfelelően alakulnak. Elemzésünkhöz validált skálákat használtunk, melyek módosításához sokkal több megalapozásra van szükség, ezért ezeknek a kritériumoknak a nem teljesülésétől és a skálák módosításától most eltekintünk.

A két minta esetében a látens endogén változók magyarázott varianciája eltérô. Míg a szolgáltatások esetében a szájreklám magyarázott varianciája 52,3\%, addig a termékek esetében ez mindössze 38,5\%, míg az újravásárlási szándék, valamint az elégedettség varianciája a termékek esetében magasabb $\left(\mathrm{R}_{\text {biт }}^{2}=0,547\right.$, $\left.\mathrm{R}_{\text {satT }}^{2}=0,371\right)$. A szolgáltatásoknál az elégedettség varianciájának mindössze 3,4\%-a kerül magyarázatra, ami nagyon alacsony értéknek számít. Ez azt a tényt támasztja alá, hogy a mért szolgáltatásminôség-dimenziók mellett egyéb faktorok is relevánsak lehetnek az elégedettség alakulása szempontjából, és érdemes lenne egy másfajta mérési eszközt használni a szolgáltatások vásárlásával kapcsolatos elégedettség mérésére.

A strukturális modell értékelése szempontjából a Cohen-féle mutatót használtuk (1988), mely mutatja, hogy egy kapcsolat, vagyis út megszüntetésével, hogy 
alakul egy endogén változó magyarázott varianciája. Az f mutató értéke, ha 0,35-nél nagyobb, akkor az adott hatás jelentős az endogén változó szempontjából, vagyis jelentősen hozzájárul a magyarázott varianciahányad növeléséhez. Amennyiben 0,15-0,35 közötti, akkor közepes, míg 0,02-0,15 közötti, akkor gyenge hatásról beszélünk (Cohen, 1988).

$$
f^{2}=\frac{\mathbf{R}_{\text {included }}^{2}-\mathbf{R}_{\text {excluded }}^{2}}{1-\mathbf{R}_{\text {included }}^{2}},
$$

ahol $\mathrm{R}_{\text {included }}^{2}$ a négyzetes korrelációs együttható a vizsgált kapcsolatot tartalmazó modell esetében, míg $\mathrm{R}_{\text {excluded }}^{2}$ a négyzetes korrelációs együttható az adott kapcsolatot nem tartalmazó modell esetében.

Az $\mathrm{f}^{2}$ mutató alapján megállapítható, hogy a szolgáltatások esetében az észlelt minôség jelentôsen befolyásolja a szájreklám magyarázott varianciájának alakulását ( $\left.\mathrm{f}^{2}{ }_{\text {qual-womsz }}=0,68\right)$, vagyis a strukturális szintet, azonban a termékek esetében jelentéktelen a hatása $\left(\mathrm{f}^{2}{ }_{\text {qual-womT }}=0,03\right)$. A minóség befolyása az újravásárlásra magyarázatában mindkét esetben igen gyenge $\left(\mathrm{f}^{2}{ }_{\text {qual-bisz }}=0,14, \mathrm{f}_{\text {qual-biT }}=0,00\right)$. Az elégedettség hatása a szájreklám látens endogén magyarázatában mindkét esetben közepes ( $\mathrm{f}^{2}{ }_{\text {sat-womsz }}=0,21, \mathrm{f}^{2}{ }_{\text {sat-womT }}=0,25$ ), míg az újravásárlással kapcsolatban a szolgáltatásoknál gyenge, a termékeknél pedig nagyon erôs ( $\mathrm{f}^{2}{ }_{\text {sat- }}$ $\left.{ }_{\text {bisz }}=0,11, \mathrm{f}_{\text {sat-biT }}^{2}=0,71\right)(4$. táblázat).

$\mathrm{Az}$ útegyütthatók értelmezése kapcsán elmondható, hogy a minőség dimenziói egy kivételével hasonló hatással bírnak a tényleges minóségészlelésre. Jelentôs eltérés csak az ügyfélszolgálat esetében figyelhetô

\begin{tabular}{|c|c|c|}
\hline \multicolumn{3}{|c|}{ A változók közti hatások jelentôsége } \\
\hline & \multicolumn{2}{|c|}{ f2 mutató } \\
\hline & Szolgáltatás & Termék \\
\hline Qual - BI & 0,14 & 0,00 \\
\hline Qual - WOM & 0,68 & 0,03 \\
\hline Sat - BI & 0,11 & 0,71 \\
\hline Sat - WOM & 0,21 & 0,25 \\
\hline
\end{tabular}

Forrás: eredmények alapján saját szerkesztés

meg, mely változó kapcsolata a teljes minôségészlelésre a termékek esetében sokkal magasabb $\left(\beta_{15 \mathrm{~T}}=0,871\right.$, $\left.\beta_{15 \mathrm{sz}}=0,676\right)$. Tehát abban az esetben, amikor a vásárlás után még hátra van a tényleges kiszállítás vagy kézhezvétel, tehát felmerülhetnek további problémák az „off-line” teljesítéshez kapcsolódóan, az ügyfélszolgálat minősítése jelentősebbnek bizonyul. Az elégedettségkövetkezményeket megvizsgálva láthatjuk, hogy a szolgáltatások esetében az észlelt elektronikus szolgáltatásminôség jelentôs hatással bír az újravásárlási szándékra $\left(\beta_{57 \mathrm{sz}}=0,351\right)$, valamint a szájreklámra $\left(\beta_{58 \mathrm{sz}}=0,586\right)$, míg az elégedettséghez kapcsolódó hatás elég gyenge $\left(\beta_{56 \mathrm{Sz}}=0,185\right)$. Ebben az esetben az elégedettség mind az újravásárlási szándékra $\left(\beta_{67 \mathrm{sz}}=0,305\right)$, mind pedig a szájreklámra $\left(\beta_{68 \mathrm{sz}}=0,329\right)$ jelentôs hatást gyakorol. Ezzel szemben a termékek esetében az észlelt minőség csak az elégedettségre bír jelentős hatással $\left(\beta_{55 \mathrm{~T}}=0,609\right)$, és az újravásárlási szándékot, valamint a szájreklámot csak az elégedettség befolyásolja jelentő$\operatorname{sen}\left(\beta_{67 \mathrm{~T}}=0,713, \beta_{68 \mathrm{~T}}=0,498\right)$ (3. és 4. ábra).

3. ábra

\section{A PLS útelemzés eredményei termékek esetében}

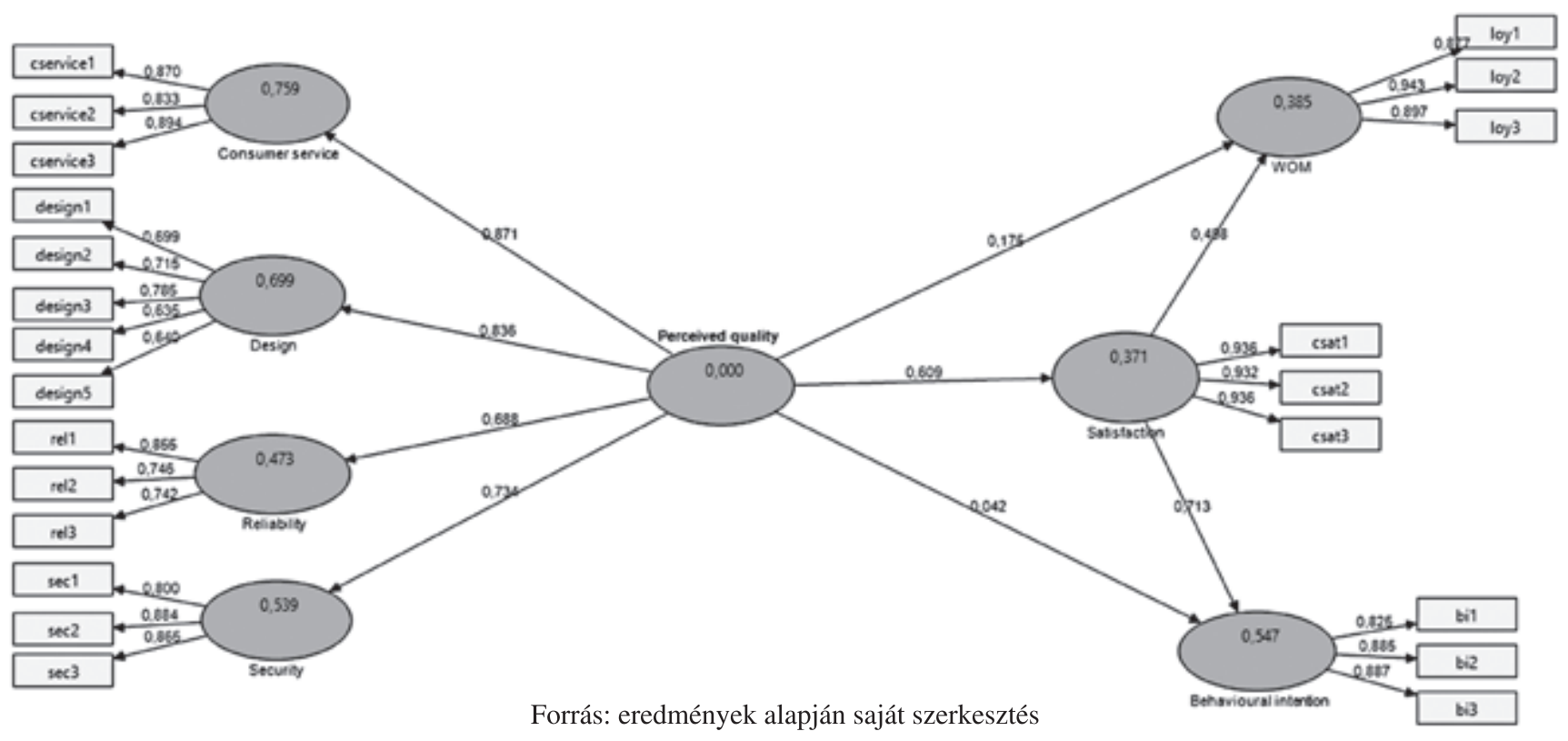




\section{A PLS útelemzés eredményei szolgáltatások esetében}

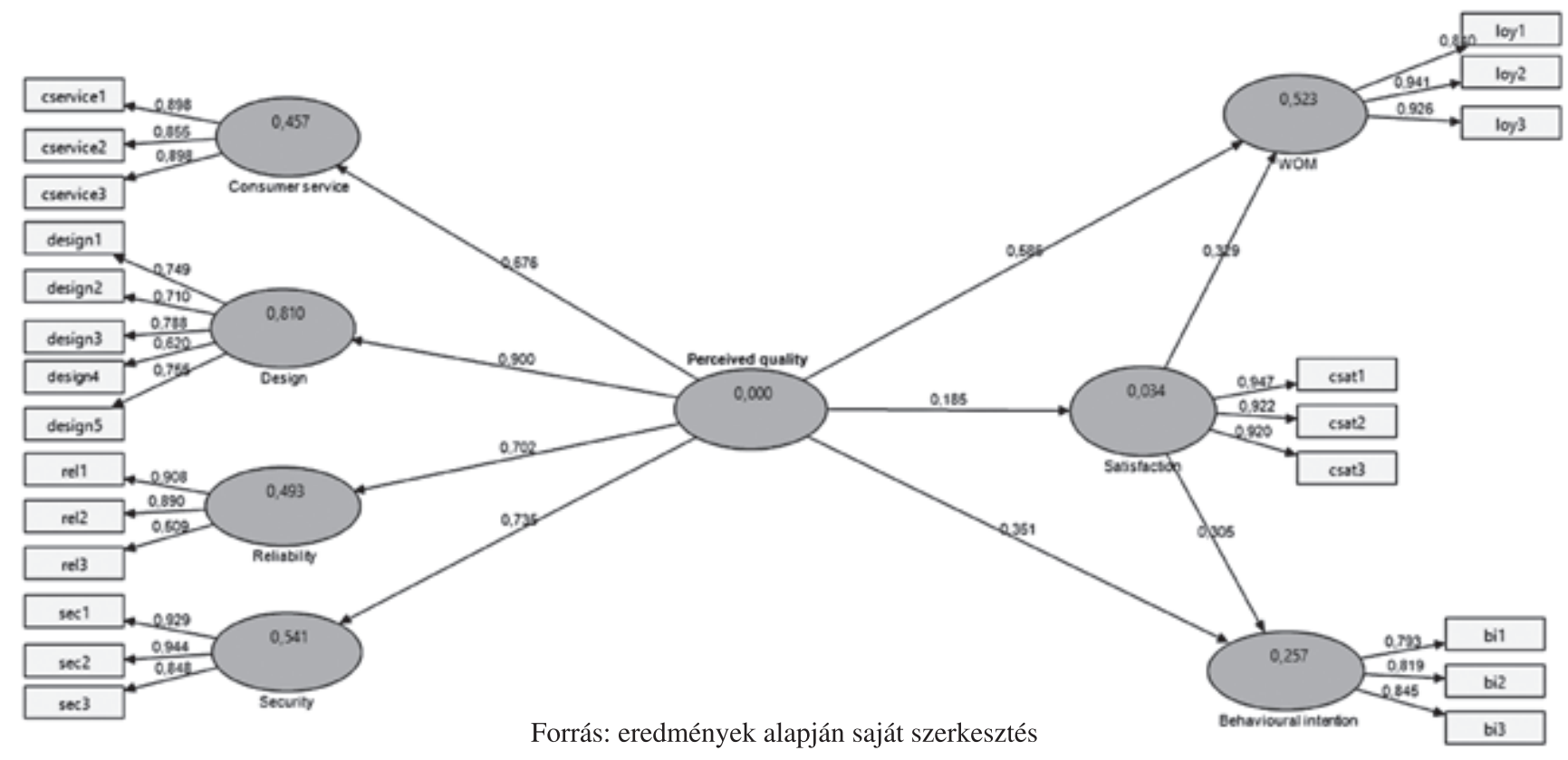

Arról, hogy a különböző útegyütthatók jelentősek-e, a következő hipotézist állítjuk fel:

H0: $\beta=0$, vagyis szignifikánsan nem különbözik 0-tól az adott együttható értéke.

H1: $\beta \neq 0$

Amennyiben megvizsgáljuk a különböző útegyütthatókhoz tartozó szignifikanciaszinteket is, akkor megállapítható, hogy a szolgáltatások esetében a 95\%-os megbízhatósági szinten az összes útegyüttható szignifikánsan különbözik 0-tól (H0-t elutasítjuk), 99\%-os megbízhatóság mellett azonban a minőség és az elégedettség közti útegyütthatóról ez nem mondható el. A termékek esetében 95\%-os megbízhatósági szinten a minőség hatása az újravásárlásra, valamint a szájreklámra azonban nem tér el szignifikánsan a 0-tól (H0-t nem utasítjuk el). Ezek alapján a felállított hipotézisek vizsgálata a következóképpen alakul (5. táblázat).

5. táblázat

\section{A hipotézisvizsgálat eredményei}

\begin{tabular}{|c|c|c|}
\hline Felállított hipotézisek & 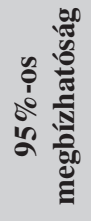 & 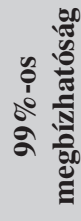 \\
\hline H1a: A szolgáltatások vásárlása esetében az elektronikus szolgáltatásminóség pozitív hatással bír az elégedettségre. & $\checkmark$ & 凶 \\
\hline H1b: A termékek vásárlása esetében az elektronikus szolgáltatásminőség pozitív hatással bír az elégedettségre. & $\checkmark$ & $\checkmark$ \\
\hline H2a: A szolgáltatások vásárlása esetében az elektronikus szolgáltatásminőség pozitív hatással bír az újravásárlási szándékra. & $\checkmark$ & $\checkmark$ \\
\hline H2b: A termékek vásárlása esetében az elektronikus szolgáltatásminóség pozitív hatással bír az újravásárlási szándékra. & 凶 & 冈 \\
\hline H3a: A szolgáltatások vásárlása esetében az elektronikus szolgáltatásminóség pozitív hatással bír a szájreklámra. & $\checkmark$ & $\checkmark$ \\
\hline H3b: A termékek vásárlása esetében az elektronikus szolgáltatásminóség pozitív hatással bír a szájreklámra. & 区 & 凶 \\
\hline H4a: A szolgáltatások vásárlása esetében az elégedettség pozitív hatással bír az újravásárlási szándékra. & $\checkmark$ & $\checkmark$ \\
\hline H4b: A termékek vásárlása esetében az elégedettség pozitív hatással bír az újravásárlási szándékra. & $\checkmark$ & $\checkmark$ \\
\hline H5a: A szolgáltatások vásárlása esetében az elégedettség pozitív hatással bír a szájreklámra. & $\checkmark$ & $\checkmark$ \\
\hline H5b: A termékek vásárlása esetében az elégedettség pozitív hatással bír a szájreklámra. & $\checkmark$ & $\checkmark$ \\
\hline
\end{tabular}

Forrás: eredmények alapján saját szerkesztés

\section{VEZETÉSTUDOMÁNY}




\section{Konklúzió és jövôbeli kutatási irányok}

Kutatásunkban az elektronikus szolgáltatásminőség, elégedettség, újravásárlási szándék és továbbajánlás kapcsolatrendszerét kívántunk megvizsgálni termékek, valamint szolgáltatások on-line vásárlása esetében. A változók mérésére validált skálákat használtunk, és az alacsony mintaelemszám miatt a PLS-SEM útelemzés módszerét alkalmaztuk. Eredményeink alapján a felállított hipotézisek többsége támogatásra került, azonban a jövőben a minőség direkt hatását az elégedettség következményeire, úgymint az újravásárlási szándékra, valamint a szájreklámra, az alacsony útegyütthatók miatt nem célszerú vizsgálni, és érdemes lenne az elégedettségen át kifejtett hatást alapul venni. Ezt a tényt már számos korábbi tanulmány is alátámasztja (Anderson - Sullivan, 1993; Gotlieb - Grewal - Brown, 1994; Patterson - Spreng, 1997; Roest - Pieters, 1997; Taylor, 1997).

Eredményeink rámutattak, hogy a terméket vagy szolgáltatást on-line vásárlók esetében megfigyelhetôk bizonyos különbségek. A vizsgált e-szolgáltatásminôség-dimenziók közül az ügyfélszolgálat minőségének észlelése a terméket vásárlók esetében fontosabbnak mutatkozik. Mindemellett azt is láthatjuk, hogy a vizsgált dimenziók az elégedettség alakulását a szolgáltatást vásárlók esetében nem magyarázzák tökéletesen, tehát érdemes a további, releváns minôségdimenziókat jövôbeli kutatásokkal feltárni. Elemzésünk során azt is láthattuk, hogy az elégedettség mediáló, vagyis közvetítő hatása a minőségészlelés és továbbajánlási, valamint az újravásárlási szándék között jelentősebb, mint a direkt hatás, különösképpen a terméket vásárlók esetében. A vizsgált modellben az újravásárlási szándék alakulását a terméket vásárlók esetében jobban tudjuk magyarázni, tehát a szolgáltatások esetében a feltételezett kapcsolat gyengébbnek számít. Ugyancsak gyengébb a szolgáltatások esetében az elégedettség hatása a továbbajánlási szándékra, vagyis a szolgáltatásmarketingból ismert gyengébb hatások az on-line vásárlás esetében is megfigyelhetôk.

Habár kutatásunk során elkülönítve vizsgáltuk a terméket és a szolgáltatást vásárlókat, mégis a jövớben érdemes lenne további szempontok szerint csoportosítani a válaszadókat, pl. teljesítés módja (off-line - on-line), ár, vagy akár az involvement alapján. Ezeket a különbségeket azonban az alkalmazott mérési változók esetében is figyelembe kell venni, hisz bizonyos dimenziók másképp értelmezhetôk (pl. az off-line termékek esetében kiszállításról, míg az e-termékek - pl. szoftver - esetében jellemezôen letöltésról beszélhetünk). A szakirodalom alapján erre a differenciált mérésre a RECIPE-skála (Francis, 2009) sokkal alkalmasabb, melynek a korábban, a szakirodalmi részben bemutatott négy e-kereskedelmi kategóriákra érvényes, testreszabott változata létezik. Az eredmények értelmezésekor nem szabad azt sem figyelmen kívül hagyni, hogy igen alacsony volt a mintaelemszám, így a kutatást érdemes a jövooben újra megvalósítani.

\section{Menedzseri következtetések}

Tanulmányunk során a kiskereskedelem egyik legdinamikusabban fejlődő területét, az e-kiskereskedelmet vettük górcsố alá, és ennek is egy marketingközpontú elemzését. Habár a vásárlási folyamatokról, döntésekról számos információ áll rendelkezésünkre az „off-line” világból, mégis az egyre növekvő tapasztalatok és szakértói vélemények azt mutatják, hogy az interneten bizonyos eltérések figyelhetók meg. Ebból kiindulva célunk az volt, hogy egy jól ismert összefüggésrendszert, vagyis a minőség, az elégedettség, az újravásárlási és a továbbajánlási szándék kapcsolatát megvizsgáljuk a hazai e-kiskereskedelem esetében a fiatalok körében. További motivációkat a szakirodalom alapos áttanulmányozásából nyertünk, mely szerint a vásárlási folyamatokat nem érdemes egyben vizsgálni - ahogy a korábbi tanulmányok többsége tette -, hanem érdemes a különböző lehetséges e-kiskereskedelmi csoportok közötti eltéréseket is elemezni és megérteni. Tanulmányunkban csoportképzô ismérvként a vásárolt jószág jellegét választottuk, vagyis elkülönítve elemeztük a termékek és a szolgáltatások vásárlását. Ezek az eredmények a webshop tervezése és üzemeltetése szempontjából számos izgalmas nézóponttal szolgálhatnak. A feltárt különbségeket érdemes azoknak is figyelembe venni, akik olyan webshopot üzemeltetnek, mely egyszerre termékeket és szolgáltatásokat is kínál. Bizonyított, hogy a változatos kínálat nagyobb elégedettséget eredményez (Agárdi, 2004), azonban a feltárt eltérő vásárlói elvárásokat is figyelembe kell venni.

Eredményeinkból láthatjuk, hogy a kutatás során megvizsgált e-szolgáltatásminôség-dimenziók hatása a két csoporton belül eltéróen alakul. Mindkét esetben hasonló hatású a webshop designjának észlelt minősége, megbízhatósága és biztonsága, azonban az ügyfélszolgálat esetében különbség figyelhetô meg: ez a dimenzió inkább a termékek esetében bír jelentős hatással. Ennek oka lehet, hogy a termékek vásárlásakor a tényleges megrendelés után még hátravan a kiszállítás, vagy a személyes átvétel, amely még egyfajta bizonytalanságot, problémafelmerülési tényezőt okozhat a vásárlókban, és emiatt az észlelt kockázatuk csökkentése érdekében a személyes kapcsolat megjelenése ebben az egyébként személytelen folyamatban nagyobb hangsúlyt kap. Ez alapján azoknak a webshopoknak, ame- 
lyek terméket (is) értékesítenek, kiemelt szerepet kell szánniuk az ügyfélszolgálat felépítésére és üzemeltetésére, mely rövid távon az elégedettség, hosszú távon pedig a siker kulcsaként szolgálhat.

Ugyancsak figyelembe kell venni a tervezés során, hogy az elégedettség és a továbbajánlás, valamint az újravásárlás kapcsolata a szolgáltatások esetében gyengébben alakul, tehát ugyanakkora elégedettség esetében a lojalitáshoz vezető tényezók alakulása alacsonyabb szintet ér el. Az újravásárlás során ez a kapcsolat megközelítőleg fele olyan erős, mint a termékeknél. Ezért a szolgáltatások on-line értékesítésekor nem elég a fogyasztói szolgáltatásminôség-észlelést és elégedettséget figyelemmel kísérni az újravásárlások előrejelzésekor, hanem más marketingeszközök felhasználása is célszerú lehet, például dinamikus árazás a szolgáltatások esetében. Ennek részletes megértése azonban egy jelentős jövőbeli kutatási irányt jelent.

\section{Lábjegyzet}

${ }^{1}$ Pearson Chi négyzet sig $=0,050$, Phi $=0,233$

${ }^{2}$ Pearson Chi négyzet sig $=0,000$, Phi $=0,450$

${ }^{3}$ Mivel a minóség egy másodlagos fogalom, ezért itt kézzel kellett kiszámolni ezt az értéket (MacKenzie et al., 2011).

\section{Felhasznált irodalom}

Adam, S. (2002): A model of Web use in direct and on-line marketing strategy. Electronic Markets, 12: p. 1-8.

Agárdi I. (2004): Horizontális stratégiai szövetségek hatása a kiskereskedelmi vállalatok marketingstratégiájára és teljesítményére az élelmiszer- és napi-cikk kiskereskedelemben. PhD-értekezés. Budapest: Budapesti Corvinus Egyetem

Bressolles, G. - Durrieu, F. - Giraud, M. (2007): The impact of electronic service quality's dimensions on customer satisfaction and buying impulse. Journal of Customer Behaviour, 6: p. 37-56.

Cohen, J.B. - Goldberg, M.E. (1970): The Dissonance Model in Post-Decision Product Evaluation. Journal of Marketing Research (JMR), 7: p. 315-321.

Cronin Jr., J.J. - Taylor, S. A. (1992): Measuring Service Quality: A Reexamination and Extension. Journal of Marketing, 56: p. 55-68.

Enet (2013): 200 Mrd Ft lesz idén az internetes kiskereskedelmi forgalom. http://www.enet.hu/hirek/200-mrdft-lesz-iden-az-internetes-kiskereskedelmi-forgalom /?lang=hu. Letöltés dátum: 2014. május 3.

Eszes I. (2011): A szóbeszéd marketing alkalmazási lehetôségeinek kiterjesztése a web kettes virtuális közösségekben. A Magyar Marketing Szövetség Marketing Oktatók Klubja 17. Országos Konferenciája, Pécsi Tudományegyetem, Pécs, 2011. augusztus 29-30.
Francis, J.E. - White, L. (2002): Pirqual: a scale for measuring customer expectations and perceptions of quality in internet retailing. Presented at the AMA Winter Educators' Conference Proceedings: p. 263.

Francis, J.E. - White, L. (2003): Utilitarian and hedonic value across fulfillment product categories of Internet shopping. AMA ServSIG Services Research Conference 2003 Chicago: American Marketing Association

Francis, J.E. (2009): Category-specific RECIPEs for internet retailing quality. Journal of Services Marketing, 23: p. 450-461.

Godwin, U.J. - Bagchi, K.K. - Kirs, P.J. (2010): An assessment of customers' e-service quality perception, satisfaction and intention. International Journal of Information Management, 30: p. 481-492.

Henseler, J. - Ringle, C.M - Sinkovics, R.R. (2009): The use of partial least squares path modeling in international marketing. Advances in International Marketing, 20: p. 277-319.

Henseler, J. (2010): On the convergence of the partial least squares path modeling algorithm. Comput Stat, Springer: p. 107-120.

Hofmeister-Tóth, Á. - Simon, J. - Sajtos, L. (2003): Fogyasztói elégedettségmérés. Budapest: Alinea Kiadó

Hong-Youl, Ha - Muthaly, S.K. - Akamavi, R.K. (2010): Alternative explanations of on-line repurchasing behavioral intentions: A comparison study of Korean and UK young customers. European Journal of Marketing, 44: p. 874-904.

Hsin, H. Ch. - Yao-Hua, W. - Wen-Ying, Y. (2009): The impact of e-service quality, customer satisfaction and loyalty on e-marketing: Moderating effect of perceived value. Total Quality Management \& Business Excellence, 20: p. 423-443.

Hsu, Ch.L. - Wu, C.Ch. - Chen, M.Ch. (2012): An empirical analysis of the antecedents of e-satisfaction and e-loyalty_focusing on the role of flow and its antecedents. Information Systsem and E-Business Management, Springer

Kenesei Zs. - Kolos K. (2007): Szolgáltatásmarketing és menedzsment. Budapest: Alinea Kiadó

Kim, D.J. (2012): An investigation of the effect of on-line consumer trust on expectation, satisfaction, and postexpectation. Information Systsem and E-Business Management, Springer

Kim, H.-R. (2005): Developing an index of on-line customer satisfaction. Journal of Financial Services Marketing, 10: p. 49-64.

Loiacono, E.T. - Watson, R.T. - Goodhue, D.L. (2007): WebQual: An Instrument for Consumer Evaluation of Web Sites. International Journal of Electronic Commerce, 11: p. 51-87.

Malhotra, N.K. - Simon, J. (km.) (2009): Marketingkutatás. Budapest: Akadémiai Kiadó

Minjeong, K. - Jung-Hwan, K. - Sharron, J.L. (2006): On-line service attributes available on apparel retail 
web sites: an E-S-QUAL approach. Managing Service Quality, 16: p. 51-77.

Moon, S.-Y. - Philip, G.C. - Moon, S. (2011): The Effects of Involvement on E-Satisfaction Models. Services Marketing Quarterly, 32: p. 332-342.

Neumann-Bódi E. (2012): Vevőértékelés egyéni és szervezeti vásárlók esetében. Az ajánlással szerzett ügyfelek jellemzői és hatásuk a vevőértékre szervezetközi viszonylatban. PhD-értekezés. Bp.: Budapesti Corvinus Egyetem

Parasuraman, A. - Zeithaml, V. A. - Malhotra, A. (2005): E-SQUAL: A Multiple-Item Scale for Assessing Electronic Service Quality. Journal of Service Research, 7: p. 213-233.

Petre, M. - Minocha, S. - Roberts, D. (2006): Usability beyond the website: an empirically-grounded e-commerce evaluation instrument for the total customer experience. Behaviour \& Information Technology, 25: p. 189-203.

Seiders, K. - Berry, L.L. - Gresham, L.G. (2000): Attention, Retailers! How Convenient Is Your Convenience Strategy? Sloan Management Review, 41: p. 79-89.

Sheng-Hsun, H. - Wun-Hwa, C. - Ming-Jyh, H. (2006): Robustness testing of PLS, LISREL, EQS and ANN-based SEM for measuring customer satisfaction. Total Quality Management \& Business Excellence, 17: p. 355-371.
Szymanski, D.M - Henard, D.H. (2001): Customer Satisfaction: A Meta-Analysis of the Empirical Evidence. Journal of the Academy of Marketing Science, 29: p. 16-35.

Van Dolen, W.M. - Dabholkar, P.A. - de Ruyter, K. (2007): Satisfaction with On-line Commercial Group Chat: The Influence of Perceived Technology Attributes, Chat Group Characteristics, and Advisor Communication Style. Journal of Retailing, 83: p. 339-358.

Wei-Lun, C. - Yu-Ting, H. (2011): A mixture model to estimate customer value for e-services. Kybernetes, 40 : p. 182-199.

Wolfinbarger, M. - Gilly, M.C. (2003): eTailQ: dimensionalizing, measuring and predicting retail quality. Journal of Retailing, 79: p. 183-198.

Yoo, B. - Donthu, N. (2001): Developing a scale to measure the preceived quality of an internet shopping site: SITEQUAL. Quarterly Journal of Electronic Commerce: p. 1-19.

Zeithaml, V.A. - Parasuraman, A. - Malhotra, A. (2002): Service Quality Delivery Through Web Sites: A Critical Review of Extant Knowledge. Journal of the Academy of Marketing Science, 30: p. 362-375. 